be compared with the 'type' specimens held in museums, and named according to prescribed taxonomic rules. The need for a rational method of organizing biodiversity requires the discipline of systematics, which arranges taxa - such as species and genera - into classifications (that may or may not reflect their phylogenetic relationships).

"Collections are absolutely essential to biodiversity research," says Prance. Creating

\title{
Funding for renovation is the top priority
}

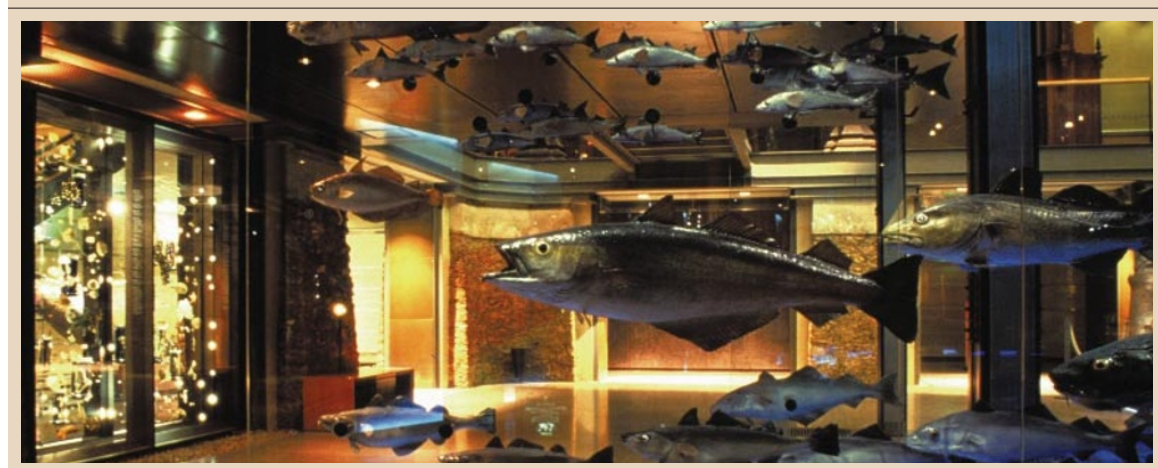

Flying fish: successful refurbishment at France's Muséum National d'Histoire Naturelle.

US researchers visiting the Muséum National d'Histoire Naturelle in Paris are surprised to learn that they can leave transformers for their binocular microscopes and other electrical devices in their hotel rooms. The museum's electrical system is antiquated - like much of the rest of the museum - and still operates at $\mathbf{1 1 0}$ volts, whereas the rest of Europe switched to 240 volts decades ago.

The dire state of the vast museum is an extreme example of a problem facing many of the world's natural history museums. Their collections are deteriorating, and there is an urgent need for expensive and well organized storage and research conditions to keep specimens free from insects, dust and extremes of temperature and humidity.

An example of what renovation can achieve comes from the Smithsonian Institution in Washington, DC, which has transferred 20 million specimens from the museum's cramped quarters to a purposebuilt 50,000-square-metre storage and research centre in Suitland, just south of the capital. This is a far cry from the Paris museum, where collections are often piled in boxes in corridors, and where a fire in 1995 came within metres of one of the world's richest herbariums, a tinderbox of 8 million specimens (see Nature 385, 378; 1997).

A recent report by France's interministerial committee for national public works warns that the museum will face a crisis unless the government launches a massive refurbishment programme. "If no new investments are made, tomorrow it will be the laboratories that face closure," it says.

The Paris museum's collections are a complete inventory of life on Earth is impossible without reference to museum specimens, while the associated taxonomy and systematics is needed to make rational decisions about conservation.

Imagine, for example, that an oceanic state wishes to develop conservation policies for an island having ten endemic bird species. If systematic studies show that nine of the species are close relatives, but that the

rivalled only by those of the Smithsonian Institution and London's Natural History Museum. They include 2 million fossils, 150 million insects, and 1.5 million vertebrates, including 1 million fish, 200,000 amphibians and reptiles, and 272,000 birds and mammals - not to mention a myriad of geological specimens including seven kilometres of 'carrots' from ocean drilling.

Henry de Lumley, the museum's director, says his "number one priority" is to renovate the collections, which currently receive just FF2 million (US\$330,000) a year. The report will provide him with ammunition for his proposal to the state's major public works funds for a FF2 billion, 15-year renovation programme, similar to the FF500 million renovation of the museum's Great Hall of Evolution (see Nature 362, 280; 1993).

Refurbishment of collections is also a burning issue at the Natural History Museum in London, even though its finances are in much better shape than those of the Paris museum, following a decade of harsh austerity measures (see page 119). "We are really concerned about the state of our collections," says Steve Blackmore, keeper of botany. "Establishing the need for that expenditure is something that we need to continue pressing our case for."

The London museum is able to pay for a planned $\mathfrak{E} 300,000$ (US\$500,000) rehousing of its 6 million herbarium specimens from its own resources. But an urgently required 15year renovation of its other collections housed in unsuitable Victorian buildings estimated to cost $\mathfrak{E 6 0}-80$ million — is well beyond the museum's means, and will require a special fundraising effort. tenth represents a distinct lineage, the most cost-effective policy might be to focus conservation measures on protecting the tenth species, as its loss would be more significant than that of one of the nine related species.

Mexico is already applying such logic to the state of Veracruz, whose biodiversity has been best described. It is trying to build a picture of the abundance and distribution of the state's biota, and its endemic species, using information derived from museums worldwide on 137,500 specimens of 7,300 species — including butterflies, birds, mammals, reptiles, amphibians, plants, fungi, earthworms and dragonflies. This baseline data is being used to plan ecological management and conservation strategies.

Some are already seek-

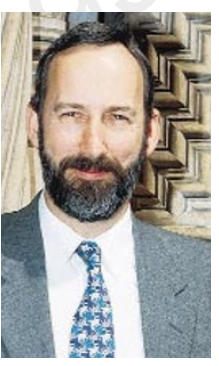

Blackmore: focus on cooperation ing to extend this to a

global scale. For example, Systematics Agenda 2000 is a proposed US $\$ 3$ billion initiative that aims to understand the 'big picture' of evolutionary history, by discovering, describing and classifying every species on Earth, so completing the research tasks begun by Darwin and Linnaeus.

The proponents of Systematics Agenda 2000 argue that, although 1.75 million species have been described, the total number is thought to be somewhere between 6 million and 100 million (according to a Global Biodiversity Assessment published by the United Nations in 1994). And, with just 15-20,000 new species being described annually, a rapid acceleration is needed.

"We are talking about exploring the entire biosphere of a whole planet, and ideally within a few decades, as much of that diversity is going to disappear," says Quentin Wheeler, a researcher at Cornell University and a former president of the Association of Systematics Collections. "Imagine you told people it was Mars, and that there were 100 million species there and that as many as a quarter might be gone in 30 years - there would be a huge outcry to launch missions and learn about it before it was gone."

The programme was launched by the American Society of Plant Taxonomists, the Society of Systematic Biologists, and the Willi Hennig Society. According to many observers, it lost some of its initial momentum when museums and other participating institutions became preoccupied with their own financial difficulties.

But it has recently regained prominence following its absorption into a broad international umbrella biodiversity organization, Diversitas, set up under the auspices of the United Nations Educational, Scientific and Cultural Organization, and the International Council for Scientific Unions, and sup- 